\title{
PENERAPAN PEMBELAJARAN BERBASIS MASALAH UNTUK MENINGKATKAN PENGUASAAN KONSEP DAN KETERAMPILAN BERPIKIR KREATIF
}

\author{
Raehan', Kurniawan Arizona $^{2}$, dan Bahtiar ${ }^{3}$ \\ 1 Program Studi Tadris Fisika, Fakultas Tarbiyah dan Keguruan (FTK), Universitas Islam \\ Negeri (UIN) Mataram, Jln. Gajah Mada No. 100 Jempong, Mataram, 83116, Indonesia. \\ 2.Prodi Tadris Fisika, FTK UIN Mataram, Jln. Gajah Mada No. 100 Jempong, Mataram, 83116, \\ Indonesia. \\ 3. Prodi Tadris Fisika, FTK UIN Mataram, Jln. Gajah Mada No. 100 Jempong, Mataram, 83116, \\ Indonesia. \\ e-mail: Raehanphysic1901@gmail.com
}

\begin{abstract}
ABSTRAK
Penelitian ini bertujuan mengetahui peningkatan terhadap penguasaan konsep dan keterampilan berpikir kreatif peserta didik setelah diterapkannya model pembelajaran berbasis masalah. Sampel dalam penelitian adalah peserta didik kelas VIII MTs Ad-Diinul Qayyim dengan menggunakan pendekatan kualitatif dan jenis penelitian tindakan kelas. Adapun materi yang digunakan adalah Tekanan Zat. Penelitian ini dilaksanakan pada semester kedua tahun pelajaran 2018/2019. Instrumen yang digunakan meliputi 1) lembar observasi keterlaksanaan pembelajaran oleh guru; 2) lembar observasi aktivitas peserta didik; 3) instrumen tes penguasaan konsep dan instrumen tes keterampilan berpikir kreatif berupa soal essay. Hasil penelitian menunjukkan bahwa pembelajaran berbasis masalah dapat meningkatkan peguasaan konsep dan keterampilan berpikir kreatif, dengan diproleh skor sebagai berikut: Untuk penguasaan konsep pada siklus I diperoleh 65.52\% dan siklus II 89.65\%. Sedangkan keterampilan berpikir kreatif dengan menggunakan tes berupa soal essay diperoleh 37.93\% dan siklus II 93\%.
\end{abstract}

Kata kunci: PBM, Penguasaan Konsep, KBK

\begin{abstract}
This study aims to find out the improvement in students' mastery of concepts and creative thinking skills after the application of problem-based learning models. The sample in this study were students of class VIII MTs Ad-Diinul Qayyim by using a qualitative approach and type of classroom action research. The material used is Substance Pressure. This research was conducted in the second semester of the 2018/2019 school year. The instruments used included 1) observation sheet of the implementation of learning by the teacher; 2) student observation sheet activity; 3) the concept mastery test instrument and the creative thinking skills test instrument in the form of essay questions. The results showed that problem-based learning can improve the mastery of concepts and creative thinking skills, with the following scores obtained: For the mastery of concepts in cycle I gained $65.52 \%$ and cycle II 89.65\%. While creative thinking skills using tests in the form of essay questions were obtained $37.93 \%$ and second cycle $93 \%$.
\end{abstract}

Keywords: PBM, Mastery of Concepts, KBK

DOI: http://dx.doi.org/10.15575/jotallp.v45i1.5755

Received: 23 Agustus 2019 ; Accepted: 31 Januari 2019 ; Published: 29 Februari 2020 


\section{PENDAHULUAN}

Permasalahan yang diuraikan menunjukkan bahwa peserta didik masih kesulitan dalam menyelesaikan permasalahan yang diberikan. Artinya, dalam menyelesaikan permasalahan tersebut, peserta diidk belum mampu memahami dan terampil dalam melakukan tahapan-tahapan yang harus diperbaiki pada saat proses pembelajaran. Pembelajaran selama ini dilaksanakan belum optimal. Hal ini disebabkan ada peserta didik yang dominan dan aktif dan ada peserta didik yang pasif, sehingga pembelajaran belum maksimal. Berdasarkan hasil observasi yang diperoleh pada saat wawancara untuk tahun pelajaran 2018/2019 diperoleh data yang menunjukkan bahwa peserta didik belum maksimal terhadap penguasaan konsep dan keterampilan berpikir kreatif yaitu pada. Untuk penguasaan konsep secara klasikal hanya 65\%, sedangkan keterampilan berpikir kreatif sebesar $62.75 \%$.

Cara yang digunakan untuk mengukur tingkat penguasaan konsep siswa dilakukan dengan penerapan taksonomi Bloom dalam Anderson \& Karthwohl (2010) untuk mengukur proses kognitif siswa. Adapun kategori-kategori dalam dimensi proses kognitif siswa yaitu; (1) Mengingat, mengambil kembali pengetahuan dari memori jangka panjang. Aspek ini mengacu pada kemampuan mengenal dan mengingat materi yang sudah dipelajari dari yang sederhana sampai pada hal-hal yang sukar. (2) Memahami, mengkonstruksi makna dari materi pembelajaran, termasuk apa yang diucapkan, ditulis dan digambar oleh guru. (3) Mengaplikasikan, menerapkan atau menggunakan suatu prosedur dalam keadaan tertentu. (4) Menganalisa, memecah-mecah materi manjadi bagian-bagian penyusunnya dan menentukan hubungan-hubungan antarbagian itu dan hubungan antara bagian-bagian tersebut dan keseluruhan struktur dan tujuan. (5) Mengevaluasi, mengambil keputusan berdasarkan kriteria dan/atau standar. (6) Mencipta, memadukan baian-bagian untuk membentuk sesuatu yang baru dari koheren atau membuat suatu prodek yang orisinal. Sedangkan Munandar (2009), memberikan beberapa indikator kemampuan berfikir kreatif, yaitu: (1) berfikir lancar (fluency), (2) berfikir luwes (Flexibility), (3) berfikir orisinil (originality) dan (4) berfikir memerinci.

Berdasarkan hasil observasi dan wawancara yang dilakukan pada tanggal 24 Maret 2019 memperlihatkan dengan jelas yang muncul pada peserta didik kelas VIII E MTs Ad-Diinul Qayyim adalah masih menekankan pada aspek pengetahuan dan pemahaman materi. Selama ini guru lebih banyak memberikan latihan dan mengerjakan soal-soal yang terdapat pada buku paket peserta didik. Hal inilah yang menyebabkan kurang terlatihnya kemampuan peserta didik terhadap penguasaan konsep dan keterampilan berpikir kreatif. Oleh karena itu, untuk dapat merangsang penguasaan konsep serta keterampilan berpikir kreatif, diperlukan adanya model pembelajaran yang mendukung dan mengarahkan peserta didik untuk dapat mengatasi permasalahan yang mereka hadapi. Kemampuan tersebut adalah kemampuan dalam memecahkan masalah, yang dimana kemampuan ini dapat dikembangkan melalui pembelajaran dimana masalah dihadirkan di dalam kelas dan peserta didik dimina untuk menyelesaikan dengan segala pengetahuan dan keterampilan yang mereka miliki (Shinta, dkk., 2016) .

Berdasarkan permasalahan di atas perlu diupayakan inovasi-inovasi model pembelajaran meliputi penerapan strategi, metode dan pendekatan pembelajaran yang inovatif. Salah satu model pembelajaran yang dapat melatih siswa untuk mampu meningkatkan penguasaan konsep dan berpikir kreatif adalah model pembelajaran Problem Based Learning (PBL). PBL terpusat melalui masalah-masalah yang relevan dan siswa diarahkan untuk mencari situasi masalah. Proses pencarian tersebut diharapkan dapat menguji kesenjangan antara pengetahuan dan keterampilan mereka untuk menemukan informasi mana yang perlu diperoleh untuk menyelesaikan dan mengelola 
situasi masalah yang ada (Bukhori \& Ibrohim, 2015, p.218).

Dengan demikian proses pembelajaran menjadi lebih menarik dan bermakna sebab peserta didik memperoleh pengalaman langsung dari hasil eksperimen yang dilakukan. Dan dalam penelitian ini penulis mencoba menerapkan salah satu model pembelajaran, yaitu model pembelajaran berbasis masalah untuk mengetahui apakah dengan menggunakan model tersebut dapat meningkatkan penguasaan konsep dan keterampilan berpikir kreatif dalam pembelajaran IPA (fisika) atau tidak.

Adapun tujuan dari penelitian ini adalah untuk mengetahui: 1) penerapan model pembelajaran berbasis masalah dalam meningkatkan penguasaan konsep peserta didik MTs Ad-Diinul Qayyim kelas VIII E pada materi tekanan zat, 2)penerapan model pembelajaran berbasis masalah dalam meningkatkan keterampilan berpikir kreatif peserta didik MTs Ad-Diinul Qayyim kelas VIII E pada materi tekanan zat.

\section{METODE PENELITIAN}

Penelitian tindakan kelas ini dilaksanakan terhadap peserta didik kelas VIII E MTs Ad-Diinul Qayyim beralamatkan di Dusun Kapek, Desa Gunungsari, Kabupaten Lombok Barat, yang berjumlah 29 orang. Penelitian ini berkolaborasi dengan satu orang observer yaitu guru IPA khususnya pada mata pelajaran fisika yang ada di sekolah tersebut. Penelitian tindakan kelas ini dilakukan dalam suatu kelas tertentu untuk mencermati kegiatan pembelajaran yang berupa sebuah tindakan.

Tindakan diberikan oleh guru atau dengan arahan dari guru yang dilakukan oleh peserta didik. Secara garis besar terdapat empat langkah yang dilakukan dalam penelitian tindakan kelas. Adapun langkah-langkah berikut sesuai dengan model Kurt Lewin yaitu perencanaan, tindakan, pengamatan, dan efleksi.

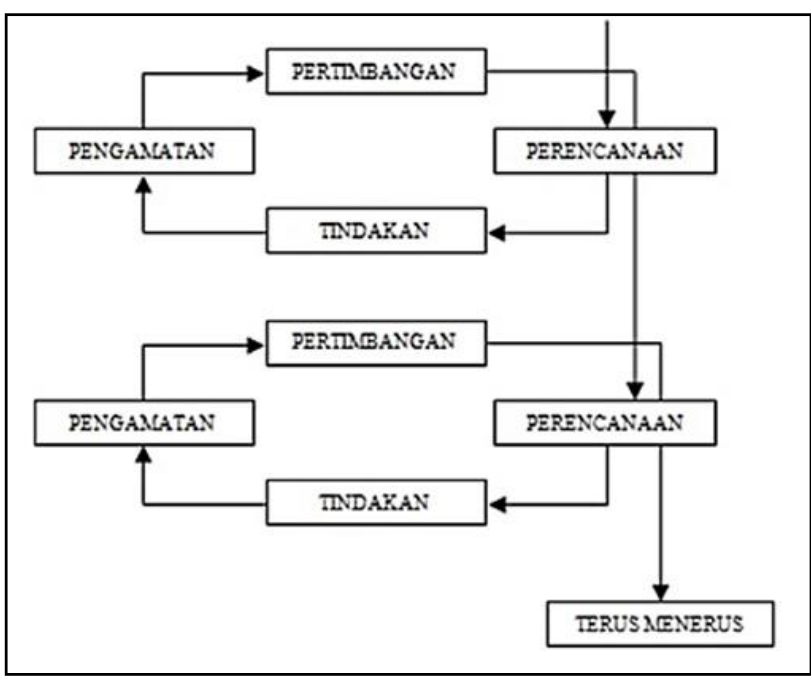

Gambar 1. Bagan Prosedur PTK model Kurt Lewin

Pada penelitian ini jika siklus pertama tidak berhasil, yaitu proses belajar mengajar dengan menggunakan penerapan pembelajaran berbasis masalah (problem based learning) belum dapat meningkatkan penguasaan konsep dan keterampilan berpikir kreatif yang terlihat dari proses belajar mengajar fisika, maka akan diadakan siklus lanjutan sampai peningkatan terhadap penguasaan konsep ataupun keterampilan berpikir kreatif peserta didik tercapai. Penelitian tindakan kelas termasuk penelitian kualitatif meskipun data yang diperoleh dapat bersifat deskriptif dalam bentuk kata-kata, peneliti merupakan instrumen utama dalam pengumpulan data.

Perhatian peneliti diarahkan kepada pemahaman bagaimana berlangsungnya suatu kejadian atau efek dari suatu tindakan tersebut. Rencana kegiatan penelitian dimulai dengan studi pendahuluan (penelitian pendahulan/ observasi awal) tentang pola proses pembelajaran yang dilaksanakan guru di dalam kelas. Dalam penelitian ini, peneliti menggunakan dua siklus. Setiap siklus terdiri dari beberapa kegiatan utama, yaitu perencanaan, tindakan, observasi dan refleksi.

Berdasarkan variabel-variabel yang akan diteliti, instrumen penelitian yang digunakan dalam 
penelitian ini terdiri dari instrumen pelaksanaan pembelajaran dan instrumen pengambilan data. Instrumen pelaksanaan pembelajaran meliputi: a) Silabus yaitu rencana pembelajaran pada suatu kelompok mata pelajaran dengan tema tertulis yang mencakup standar kompetensi, kompetensi dasar, materi pembelajaran, indikator, alokasi waktu, dan sumber belajar yang dikembangkan dalam setiap satuan pendidikan; b) Rencana pelaksanaan pembelajaran (RPP) atau lebih dikenal dengan rencana pembelajaran (RP) adalah rencana yang menggambarkan prosedur dan manajemen pembelajaran untuk mencapai satu atau lebih kompetensi dasar yang ditetapkan dalam standar isi yang dijabarkan dalam silabus; c) Lembar Kerja Peserta Didik (LKPD) adalah alat bantu dalam kegiatan belajar mengajar agar pelaksanaan pembelajaran dapat berjalan dengan lancar dan efektif.

Selanjutnya, instrumen pengambilan data meliputi instrumen tes. Instrumen tes digunakan untuk memperoleh data penguasaan konsep dan keterampilan berpikir kreatif peserta didik pada ranah kognitif. Instrumen tes berupa tes essay dan tes ini merupakan serentetan pertanyaan atau latihan yang digunakan untuk mengukur keterampilan, pengetahuan, intelegensi, kemampuan atau bakat yang dimiliki masingmasing individu maupun kelompok.

\section{HASIL DAN PEMBAHASAN}

Hasil deskripsi siklus I dapat dilihat bahwa skor yang diperoleh pada aktivitas guru sebesar 70\% dan aktivitas peserta didik 60\%. Sedangkan hasil deskripsi untuk tes penguasaan konsep 65.52\% dan tes keterampilan berpikir kreatif peserata didik sebesar 37.93\%. Pada siklus II mengalami peningkatan secara signifikan yaitu diperoleh skor untuk aktivitas guru sebesar 90\% dan aktivitas peserta didik 85\%. Sedangkan hasil penguasaan konsep 89.65\% dan tes keterampilan berpikir kreatif peserata didik sebesar 93\%.
Penelitian yang bertujuan untuk memperbaiki proses pembelajaran dalam upaya meningkatkan penguasaan konsep dan keterampilan berpikir kreatif peserta didik melalui model pembelajaran berbasis masalah (problem based learning). Kegiatan belajar mengajar guru dan aktivitas peserta didik di dalam kelas dari siklus I ke siklus II ternyata mengalami peningkatan. Ini dibuktikan dengan hasil yang telah diperoleh dari setiap siklus menggunakan model pembelajaran berbasis masalah (problem based learning) yang telah diterapkan. Perbandingan hasil antara aktivitas guru dan aktivias peserta didik dalam 2 siklus dapat dilihat dalam tabel berikut.

Tabel 1. Perbandingan Observasi Aktivitas Guru dan Peserta Didik

\begin{tabular}{clcc}
\hline No & Observasi & Siklus I & Siklus II \\
\hline 1 & $\begin{array}{l}\text { Aktivitas } \\
\text { Guru }\end{array}$ & $70 \%$ & $90 \%$ \\
\hline 2 & $\begin{array}{l}\text { Aktivitas } \\
\text { Siswa }\end{array}$ & $60 \%$ & $85 \%$ \\
\hline
\end{tabular}

Pada pelaksanaan siklus II dengan menggunakan model pembelajaran berbasis masalah (problem based learning), penguasaan konsep peserta didik secara teoritik dengan menggunakan tes yang berupa soal essay diperoleh skor $89.65 \%$. Untuk tes keterampilan berpikir kreatif dengan menggunakan soal berupa essay diperoleh skor 93\%. Untuk kedua tes tersebut tidak perlu dilanjutkan ke siklus berikutnya karena telah mengalami peningkatan yang signifikan. Perbandingan hasil tes antara penguasaan konsep dan keterampilan berpikir kreatif aktivias peserta didik dalam 2 siklus dapat dilihat melalui Tabel 2. 
Tabel 2. Perbandingan Observasi Aktivitas Guru dan Peserta Didik

\begin{tabular}{llcc}
\hline No & Observasi & Siklus I & Siklus II \\
\hline 1 & $\begin{array}{l}\text { Penguasaan } \\
\text { Konsep }\end{array}$ & $65.52 \%$ & $89.65 \%$ \\
\hline 2 & KBK & $37.93 \%$ & $93 \%$ \\
\hline
\end{tabular}

Berdasarkan hasil analisis data penelitian, diperoleh bahwa pembelajaran menggunakan model pembelajaran berbasis masalah (problem based learning) dapat memperbaiki penguasaan konsep dan keterampilan berpikir kreatif peserta didik khususnya pada materi tekanan zat. Dengan model pembelajaran berbasis masalah (problem based learning) mengutamakan peserta didik dalam belajar dan dalam menyelesaikan permasalahan-permasalahn yang ada, baik dalam materi maupun dalam mengerjakan tugastugas yang diberikan guru berkenaan dengan materi yang diberikan. Selain itu, model pembelajaran ini menggunakan masalah dunia nyata sebagai suatu konteks bagi peserta didik untuk belajar tentang cara berpikir kreatif dan keterampilan pemecahan masalah, serta untuk memperoleh pengetahuan konsep yang esensial dari materi yang dipelajari.

Seperti penelitian yang telah dilakukan oleh Muslim, dkk. (2015) menunjukkan bahwa peningkatan penguasaan konsep siswa dengan model pembelajaran PBL secara signifikan lebih tinggi. Dan dalam peneitian yang telah dilakukan oleh Siska, dkk. (2015) menunjukkan bahwa model problem based learning juga dapat melatih siswa untuk memecahkan suatu masalah yang dihadapinya secara mandiri. Dengan pembelajaran berbasis masalah peserta didik mampu berpikir secara kreatif dan mengembangkan inisiatif serta dapat memperoleh pengetahuan dan konsep yang esensial dari materi pelajaran. Senada dengan hasil penelitian Awal dkk. (2017) menunjukkan pembelajaran masalah melalui keterampilan proses sains berpengaruh terhadap berpikir kreatif siswa pada materi sistem gerak. Hal ini diperkuat dengan studi Gusti (2017) menunjukkan adanya Pengaruh pembelajaran berbasis masalah berbantuan mind map terhadap keterampilan berpikir kreatif dan hasil belajar pada siswa SMK.

\section{KESIMPULAN}

Berdasarkan hasil penelitian dan pembahasan, dapat disimpulakan bahwa kemampuan terhadap penguasaan konsep dan keterampilan berpikir kreatif peserta didik dapat ditingkatkan melalui penerapan model pembelajaran berbasis masalah (problem based learning). Peningkatan masingmasing indikator dari penguasaan konsep dan keterampilan berpikir kreatif peserta didik tersebut dapat dilihat dari hasil penelitian yag telah dilakukan. Untuk penguasaan konsep pada siklus I diperoleh skor $65.52 \%$ dan pada siklus II diperoleh 89.65\%. Sedangkan untuk keterampilan berpikir kreatif menggunakan tes yang berupa soal essay diperoleh skor $37.93 \%$ dan pada siklus II diperoleh 93\%.

\section{DAFTAR PUSTAKA}

Anderson, L. W. \& Krathwohl, D. R. 2010. A Taxonomy for Learning, Teaching, and Assessing a Revision of Bloom's Taxonomy of Educational Objectives. New York: Longman, Inc.

Awal, Raudhah, \& Sari, I. (2017). Pembelajaran Berbasis Masalah melalui Keterampilan Proses Sains terhadap Berpikir Kreatif Siswa pada Materi Sistem Gerak Kelas XI IPA 2 T.A 2015/ 2016 SMA Nurul Falah Pekanbaru, Jurnal Pendidikan, 8 (1), 66-74.

Bukhori,I. \& Ibrahim. (2015). Penerapan Model Problem Based Learning Pada Matakuliah Ekologi Tumbuhan Untuk Meningkatkan Penguasaan Konsep Dan Keterampilan Berpikir Kreatif Mahasiswa Pendidikan Biologi Universitas Muhammadiyah Malang 2014/2015. (Malang: Program Studi Pendidikan Biologi, Pascasarjana, 2015). hlm: 617-723.

Gusti. (2017). Pengaruh Pembelajaran Berbasis Masalah Berbantuan Mind Map Terhadap 
Keterampilan Berpikir Kreatif dan Hasil Belajar Biologi Pada Siswa SMK, Jurnal Ilmiah Pendidikan dan Pembelajaran, 1(1), 68-77.

Munandar, Utami. 2009. Pengembangan Kreatifitas Anak Berbakat. Jakarta : Rineka Cipta

Muslim,I., Halim,A., \& Safitri, R. (2015). Penerapan Model Pembelajaran PBL untuk Meningkatkan Penguasaan Konsep dan Keterampilan Berpikir Kreatif Siswa Pada Konsep Elastisitas dan Hukum Hooke Di SMA Negeri Unggul Harapan Persada, Jurnal Pendidikan Sains Indonesi, 3 (2), 38.

Shinta, Ahmad, \& Gunawan. (2016). Pengaruh Model Pembelajaran Berbasis Masalah Berbantuan Simulasi Virtual Terhadap Penguasaan Konsep dan Kreativitas Fisika Siswa SMAN 2 Mataram, Jurnal Pendidikan Fisika dan Teknologi, II (3), 123-128.

Siska, Halim, A., dan Nasrullah. (2015). Penerapan Model Problem Based Learning (PBL) Pada Konsep Usaha dan Energi Untuk Meningkatkan Keterampilan Berpikir Kritis dan Berpikir Kreatif Siswa SMA, Jurnal Pendidikan Sains Indonesia, 3 (1), 207-217. 